\title{
Christopher Pittard
}

\section{The Travelling Doll Wonder: Dickens, Secular Magic and Bleak House}

In summer 1849, a small group gathered at Winterbourne House at Bonchurch on the Isle of Wight to watch a conjuring show by “The Unparalleled Necromancer Rhia Rhama Rhoos,” a magician apparently "educated cabalistically in the Orange Groves of Salamanca and the Ocean Caves of Alum Bay” (Forster 89-90). The show promises a number of amazing set pieces, all of them 'wonders': “The Leaping Card,” "The Pyramid,” "The Conflagration,” “The Loaf of Bread,” “The Pudding,” and “The Travelling Doll” (Forster 90). The audience watch the conjuror as he makes two cards selected by the audience and replaced in the pack leap forth at his command; another card is selected, named by the conjuror, set on fire and then reproduced from the ashes; another audience member's card is locked in a box and then materialises in the middle of a freshly cut loaf of bread. It is unlikely that many in the audience would have known the means by which these effects are achieved; it is certain, however, that they knew the true identity of the unparalleled necromancer Rhia Rhama Rhoos, who was none other than Charles Dickens. In this article, I consider the connections between Dickens' fiction and the art of conjuring, what Simon During calls "secular magic” (1); that is, magic that makes no claim to the supernatural, as opposed to magic in its supernatural or anthropological guises. I consider Rhia Rhama Rhoos’ routine 'The Travelling Doll Wonder,' as a paradigm for reading Dickens' fiction, and Bleak House in particular, arguing that Esther's doll, an uncanny subject/object which disappears and reappears at crucial points of the text, is informed by Dickens' own performance with a disappearing doll that raises similar questions of perception and subjectivity. My wider aim is to demonstrate that what John O. Jordan calls "the Bleak House effect" - that is, "the novel's way of luring its characters (and its readers) to imagine 
things that might have been but never were or that exist only in their minds” (147) - can be understood in the context of a similarly hyper-phenomenological cultural practice with which Dickens engaged during the composition and publication of the novel; that is, secular magic. I argue that Dickens' interest in performance magic functions metacritically in his work, especially in Bleak House, and furthermore that while the enchantment of conjuring underpins the novel, Bleak House also draws attention to the traumatic component of secular magic. Although not traumatic in itself, the experience of conjuring resembles the (in Cathy Caruth's phrase) unclaimed experiences of trauma, and it is in Bleak House that Dickens explores the connection between these discourses.

Dickens' interest in performance magic is well evidenced in his novels, letters, and performances. As John Forster records, he was a keen observer of such performances in both England and France; for instance, on 3rd May 1853 Dickens invited Frank Stone to accompany him to a performance given by the influential French conjuror Jean Eugene Robert-Houdin at Sadlers Wells (Letters 7: 76). Such performers became the addressees, and subjects, of his writing; Dickens corresponded with magicians, in particular the hugely popular Austrian conjuror Ludwig Döbler (Letters 4: 113-4), and depicted humbler conjurors in his fiction. Sweet William, one of the travelling showmen in The Old Curiosity Shop (1840-1), makes his living through card tricks and various other conjuring routines (150-1); in Dombey and Son (1844-6), Paul Dombey's room-mate Tozer is taken by his uncle to see a conjuror (the uncle ruins the occasion by turning it into a classics examination (251)). Similarly, in Martin Chuzzlewit (1843-4) the card tricks performed by Jonas Chuzzlewit become a metaphor for his double dealing with Charity and Mercy Pecksniff (242). Household Words, too, carried writing on magic; the edition of 9 April 1859 granted its front page to Saul Dixon's extensive review of the English translation of Robert-Houdin’s Memoirs (1859). Before becoming Rhia Rhama Rhoos in 1849, Dickens had already established a Christmas tradition of magic performance. 
In a letter of 31 December 1842 to C. C. Felton, Dickens refers to his rehearsals for a Twelfth Night performance: "Forster and I have purchased between us the entire stock in trade of a conjurer, the practice and display whereof is entrusted to me.... if you could see me conjuring the company's watches into impossible tea caddies, and causing pieces of money to fly, and burning pocket handkerchiefs without hurting 'em - and practising in my own room, without anybody to admire - you would never forget it as long as you live” (Letters 3: 416). Just over a year later, in a letter of 3 January 1844 to W. C. Macready, Dickens describes how at a Christmas party "Forster and I conjured bravely... a hot plum pudding was produced from an empty saucepan, held over a blazing fire, kindled in Stanfield's hat, without damage to the lining... a box of bran was changed into a live Guinea Pig, which ran between my God child’s feet... three half crowns being taken from Major Burns and put into a tumbler-glass before his eyes did then and there give jingling answers unto questions asked of them by me” (Letters 4 : 10). Jane Carlyle commented on the performance in her letter to Jeannie Welsh:

Dickens and Forster above all exerted themselves till the perspiration was pouring down and they seemed drunk with their efforts! Only think of that excellent Dickens playing the conjuror for one whole hour-the best conjuror I ever saw - (and I have paid money to see several) - and Forster acting as his servant! - This part of the entertainment concluded with a plum pudding made out of raw flour raw eggs - all the raw usual ingredients - boiled in a gentleman's hat - and tumbled out reeking - all in one minute before the eyes of the astonished children and astonished grown people! that trick - and his other of changing ladies’ pocket handkerchiefs into comfits [....] would enable him to make a handsome subsistence let the book-seller trade go as it please! (Carlyle 220: original emphasis $)^{1}$ 
But Carlyle's opposition of conjuring to literature (and the literary marketplace) is a curious one, foreclosing the possibility of any productive comparison between the two. Indeed, in what follows I suggest that the dichotomy is a false one, and that Dickens' fictional writings draw on the narrative structures and tropes of his conjuring career.

The art was therefore clearly an important one to Dickens, but it is also one that critics have been liable to pass over. ${ }^{2}$ For instance, Paul Schlicke’s foundational analysis of Dickens’ fascination with popular entertainments only briefly mentions conjuring, a move characteristic of wider Dickens criticism, where the focus on theatricality and melodrama (in, for instance, discussions by John Glavin, Deborah Vlock, and Juliet John) has tended to overlook other forms of performance. Conjuring does not quite fit into Schlicke's wider argument that Dickens' writings were based in nostalgia for forms of entertainment that were on the verge of collapse: itinerant showmen, travelling waxwork displays, open air carnivals. Yet rather than being in decline, in the mid-nineteenth century stage magic was gaining in popularity as a heterotopic art crossing the boundaries between theatrical space, public space, and the private parlour. More broadly, the performance magic of the 1840s and 1850s gained new cultural resonances with discourses of evolutionary biology, the psychology of perception, and economics. Although writing much later, in 1900, the American psychologist Norman Triplett theorised conjuring in Darwinian terms, arguing that its popularity "rests upon a universal instinct to deception.... In the struggle of primitive man to increase his personality, conjuring came into existence” (440). Triplett was merely one of a range of later Victorian psychologists (among them Alfred Binet, Joseph Jastrow, and James Sully) who had realised the potential of conjuring to elucidate problems of perception and inattention. Conjuring also provided a useful metaphor for mid-nineteenth century economic critique, albeit one which emphasised the category of deception. For Marx and Engels, secular magic was a useful metaphor for intellectual and rhetorical dishonesty. For instance, in volume one of Capital, Marx accuses 
the American H. Carey of performing a "conjuring trick" in reconfiguring the state of slavery as developed capitalist free association, rather than bare commodity relations (671); similar rhetoric occurs in The German Ideology (1846) and Engels' Anti-Dühring (1878). Marx’s conjuring metaphors have proved of particular interest to Jacques Derrida, whose explication of hauntology in Specters of Marx (1993) is also a consideration of conjuring in all its senses, including that of secular magic. For Derrida, conjuring raises questions of phenomenology; he comments that "The word 'eskomotage' speaks of subterfuge or theft in the exchange of merchandise, but first of all the sleight of hand by means of which an illusionist makes the most perceptible body disappear. It is an art or a technique of making disappear. The escamoteur knows how to make inapparent. He is expert in a hyper-phenomenology” (159).

The idea of conjuring as hyperphenomenology offers a way into reading Bleak House in this context, as a text dependent on appearances and disappearances, in making inapparent, It is certainly concerned with the supernatural and the magical, and even (as Christopher Herbert argues) the occult, holding these in tension with the conventions of literary realism; as Dickens famously states in the preface, "I have purposely dwelt upon the romantic side of familiar things” (7). While Bleak House features few direct references to secular magic and conjurors (unlike The Old Curiosity Shop or Dombey and Son), it makes a number of oblique references to conjuring and magical performance. The magical purse of Fortunatus, out of which infinite coins can be taken, appears twice in the novel, the same magical image tying together both narrations: when Esther jokingly suggests that Richard Carstone requires such a purse as "he made so light of money" (282), and again when Cook’s Court is shaken by the news of Krook’s spontaneous combustion: “Never, since it has been a court, has it had such a Fortunatus's purse of gossip as in the proceedings at the rag and bottle shop” (632-3); the court later imagines the Smallweeds to have found "guineas pouring out of teapots, crown-pieces overflowing punch-bowls, old chairs and mattresses stuffed with Bank of England notes” 
(633). A more secular magic is referenced when Tulkinghorn is introduced as having "as many cast-iron boxes in his office with that name [Dedlock] outside, as if the present baronet were the coin of the conjuror's trick, and were constantly being juggled through the whole set” (23), a reference to the popular routine of a making a particular coin appear in a set of locked boxes, as performed by Robert-Houdin and (as described by Henry Mayhew) street conjurors across London (Mayhew 107). If we were to identify a conjuror figure in the novel, a likely candidate would be Inspector Bucket, who performs a conjuring trick in transforming from his disguise as a physician to gain access to George’s shooting gallery (“the physician stopped, and, taking off his hat, appeared to vanish by magic, and to leave another and quite a different man in his place” (401)). Bucket reprises his role as magician at the novel's climax, with the finding of the codicil that resolves Jarndyce and Jarndyce: "Mr Bucket lost no time in transferring this paper, with the dexterity of a conjuror, from Mr Smallweed to Mr Jarndyce” (947).

These examples are, however, somewhat local. For the rest of the article I wish to consider the novel's structural affinities with performance magic, and in particular to read one of Dickens' performances against Bleak House's treatment of self and identity. One of the routines Dickens performed as Rhia Rhama Rhoos in 1849 provides suggestive echoes of the novel he would begin publishing less than three years later. In the 'Travelling Doll Wonder,' Dickens would make a small doll appear, disappear, and reappear at his command, bringing back (in what seems a strikingly early parody of spiritualism) messages for the audience from distant people and places. On the playbill for Rhia Rhama Rhoos, Dickens described the trick thus:

The travelling doll is composed of solid wood throughout, but, by putting on a travelling dress of the simplest construction, becomes invisible, performs enormous journeys in half a minute, and passes from visibility to invisibility 
with an expedition so astonishing that no eye can follow its transformations. (Forster 90)

There was, in fact, no impenetrable mystery surrounding the doll, since the effect was freely commercially available, and while Dickens himself called it the Travelling Doll Wonder, the effect was more widely known amongst conjurors as "the Bonus Genius.” The routine dates back to at least 1634, when it was mentioned in the conjuring manual Hocus Pocus Iunior as involving the disappearance of a doll "the bignesse of your little finger" (cited in Butterworth 24). The secret behind the Bonus Genius was described in a number of Victorian conjuring textbooks, including the pseudonymous Professor Hoffmann's (Angelo Lewis) hugely influential manual of conjuring, Modern Magic: A Practical Treatise on the Art of Conjuring (1873). Lewis describes the doll as "four to six inches in height, and more or less grotesque in colour or design. A little cloak, made small above and full below, like the skirt of a doll's dress, and with no opening save where the head of the figure passes through, completes the apparatus” (Hoffmann 321). The doll apparatus features in Henry Mayhew's London Labour and the London Poor; in the image of a 'Street Conjuror Performing,' the doll is visible propped up against the top hat on the performer's table (Mayhew 116). Yet in Mayhew’s account, while considerable space is given over to explaining the mechanics of fire-eating and similar routines, the ‘Bonus Genius’ passes without comment. It was, by the mid-nineteenth century, something of a conjuring cliché, not worthy of further explanation. Dickens, however, found something in the routine worth revitalising.

The familiarity of the doll as a standard part of the Victorian magician's repertoire led to it being narrativised in a multiplicity of ways, often making sardonic commentary on questions of gender and colonialism. One might, following feminist analyses of secular magic by Karen Beckman, Francesca Coppa, and Lucy Fischer, read the Travelling Doll Wonder as another of the paradigmatic routines of the mid to late nineteenth and early twentieth centuries, 
enacting masculine anxieties over feminine agency, female surplus population, and masculine procreative impotence. Certainly, later Victorian versions of the doll routine installed elements of domestic satire: the London toy shop Hamley’s catalogue of conjuring tricks from the 1890s repackaged the trick as “Mrs Brown, the funny little Vanishing Woman”: “Mrs Brown, having resolved to visit Margate, borrows half-a-crown, when she suddenly disappears from her cloak in the most surprising manner, and is nowhere to be found” (Illustrated 12). The economic paradigm here is one of lending in the service of frivolity rather than earning through industry; the tempting analysis is to read the routine as fantasising the disappearance of the economically unproductive. But there are elements of the Travelling Doll Wonder that resist such easily gendered readings, one being that the femininity of the doll was by no means given. Three prominent mid-Victorian manuals of conjuring, John Henry Anderson's The Fashionable Science of Parlour Magic (1855), George Arnold and Frank Cahill’s The Magician's Own Book: or the Whole Art of Conjuring (1862), and Colonel Stodare's Stodare's Fly Notes, or Conjuring Made Easy for Juvenile Amateurs (1867) all describe a specifically male doll. Anderson's version, 'The Vanishing Puzzle' (25), almost elides the personhood of the doll altogether, reducing it to the vehicle for an enigma; Arnold and Cahill, by contrast, are detailed in their casting of the doll as an old man, a "professor of astronomy at Timbuctoo" travelling to Amsterdam to "see the eclipse of the last new comet" (29). Stodare's patter suggests a different set of more down to earth cultural references; the magician, having given the doll his money, says “you can now, if you wish, proceed on your tour to Algiers, or Dahomey, or Timbuctoo, or wherever the English travellers fancy at the present to resort” (442). ${ }^{3}$ But the other context Stodare makes clear is that of communication and travel networks, and in particular the speed of the doll in travelling; Stodare recommends that performers should "Discourse for a few minutes about sending a telegram to overtake him at Suez or Gibraltar, talk about the sea-passage, railways, tunnels, and what not” (442), though clearly the doll's 
return will outpace any telegraphic response. The Travelling Doll Wonder thus becomes, in the mid-Victorian period, a story of the annihilation of space by time, but also of the invisible information networks that connect disparate corners of the world (or, in Arnold and Cahill's version, the universe, an echo of Esther Summerson's cosmological hallucinations). Recall that Dickens' modification of the routine has the doll return with messages for its audience, having completed invisible and "enormous journeys in half a minute.” The doll becomes the rapid ghost of an emergent information technology; in relation to Dickens' work, the routine asks implicitly what Bleak House makes explicit: "What connexion can there have been between many people in the innumerable histories of this world, who, from opposite sides of great gulfs, have, nevertheless, been very curiously brought together?” (256).

How, then, does the doll disappear, supposedly perform its travels, and reappear? In Bonchurch, what the audience of Rhia Rhama Rhoos would have seen was Dickens presenting the doll to them, and then having a brief conversation with the doll, who 'asks' for travelling expenses. Dickens gives the doll a coin from his pocket; after a further comic exchange, the doll suddenly vanishes from its cloak. Screwing the cloak up into his fist allows Dickens to demonstrate that the doll, of six or so inches in height, has completely disappeared. Nevertheless, the doll reappears, now bearing messages for the audience. The key to understanding how this trick actually works lies in the fact that the doll is not, as the audience are led to believe, a single solid piece of wood, but has a detachable head. Once dressed in the cloak, the two pieces can be separated without observation. Dickens' action of looking for a coin allows him to palm (that is, conceal in hand) the doll's body and transfer it to his pocket while reaching for the coin, an action afforded further misdirection by the suggestion that something (money) is travelling to the doll rather than its body having already travelled away. The remaining head is kept in a puppet position by Dickens' fingers, and since this is the only piece that needs to disappear, it does so by Dickens allowing it to drop into a small pocket sewn 
inside the cloak. The divisibility of the doll's body is crucial to the working of the trick; the doll as a whole appears too large to conceal in a closed hand (whereas the head alone is easily managed). Thus, the description on Rhia Rhama Rhoos' playbill is already a piece of misdirection even before the performance has begun; the doll's description as being of solid wood implies a single piece rather than two, and the description of the cloak as of the simplest construction disarms suspicion as to the existence of any hidden pockets.

The clearest parallel between Dickens’ performance as Rhia Rhama Roos and Bleak House lies in that text's obsession with travelling dolls, and in particular the figure of Esther's doll, her intersubjective companion. Esther's doll first appears in the narrative shortly after Esther herself (indeed, as Robyn L. Schiffman notes, we learn Dolly's name before Esther's (164)), as confessor and as repository of secret knowledge:

I can remember, when I was a very little girl indeed, I used to say to my doll, when we were alone together, "Now, Dolly, I am not clever, you know very well, and you must be patient with me, like a dear!” And so she used to sit propped up in a great arm-chair, with her beautiful complexion and rosy lips, staring at me - or not so much at me, I think, as at nothing — while I busily stitched away, and told her every one of my secrets.

My dear old doll! I was such a shy little thing that I seldom dared to open my lips, and never dared to open my heart, to anybody else. It almost makes me cry to think what a relief it used to be to me, when I came home from school of a day, to run upstairs to my room and say, “O you dear faithful Dolly, I knew you would be expecting me!” and then to sit down on the floor, leaning on the elbow of her great chair, and tell her all I had noticed since we parted. (27-8)

Much has been made of Esther's doll, and of dolls more widely, as the transitional object theorised by D. W. Winnicott. For Winnicott, transitional objects mediate between the child 
and the mother; they form the child's first experience of 'not me,' acting as a replacement for the bond with the mother which will be lost in the creation of an individuated self. Winnicott points out that "It is not the object, of course, that is transitional. The object represents the infant's transition from a state of being merged with the mother to a state of being in relation to the mother as something outside and separate” (19-20). In regard to Bleak House, Carolyn Dever reads Dolly in this way as a "compensat[ion] for the multiply overdetermined markers of absence in [Esther’s] world” (88). Like Dickens’ travelling doll, returning to bear news for its audience, Dever points out that "With uncanny prescience, Esther foregrounds her paternal identity in her discussion with her doll” (88); the doll looks at Esther as if she were 'nothing,' the daughter of Nemo, or 'nobody.' Dickens, often lauded as pre-Freudian, here anticipates Winnicott; elsewhere in Bleak House, Judy Smallweed's stunted emotional growth is explained by reference to her lack of a transitional object, that she "never owned a doll, never heard of Cinderella, never played at any game” (335). Yet reading Esther's doll in the cultural context of magic adds another dimension to these familiar Winnicottian readings. Winnicott argues that another transition takes places through an object such as a doll: "In relation to the transitional object the infant passes from (magical) omnipotent control to control by manipulation (involving muscle erotism and coordination pleasure)” (12). Through such an object, the child's subjective omnipotence is challenged, and s/he comes to realise that desires cannot always be met by magical acts of willing them so (in the sense that, for Winnicott, the “mother's adaptation to the infant's needs... gives the infant the illusion that there is an external reality that corresponds to the infant's own capacity to create” (16; original emphasis)). Through the transitional object, the child loses one magical mode of thought, but gains another: the world may not be hers to control omnipotently, but in reality testing in this way the infant constructs a real world, with limits and laws, which can then be undermined by acts of secular magic. In other words, the transitional stage marks the beginning of the creation of the 
necessary psychic circumstances for the appreciation of performance magic, the mimetic stage which can then be challenged by the skill of the magician. In short, there can be no secular magic without the transitional object.

Returning to Esther’s transitional object, at first Dolly seems resolutely static, a mimetic representation of an actual doll; it is Esther who moves back and forth. Dolly's uncanny movements begin following the death of Esther's godmother and the move to Greenleaf School, before which Esther buries her doll:

My godmother had left Mrs Rachael all the little property she possessed; and there was to be a sale; and an old hearth-rug with roses on it, which always seemed to me the first thing in the world I had ever seen, was hanging outside in the frost and snow. A day or two before, I had wrapped the dear old doll in her own shawl, and quietly laid her - I am half ashamed to tell it — in the garden-earth, under the tree that shaded my old window. (36)

Dolly, it seems, has competition for Esther's affections as transitional object; the description of the rug as having "always seemed to me the first thing in the world" recalls Winnicott's characterisation of the object as the child's first experience of 'not me' (Winnicott 2). Esther folds one transitional object into another, burying Dolly in the garden of which the rug is the simulacrum. Esther, like Rhia Rhama Rhoos, must dress the doll in "her own shawl" before effecting her disappearance, and the grave is apparently sealed by the implied covering of snow over her grave, anticipating the later melting snow that reveals the body of Lady Dedlock. But this is not the end of Dolly. In one of the characteristic disappearances and reappearances of the novel (and of Dickens' conjuring routines), the doll reappears at crucial moments in the novel: when reflecting on Guppy’s affections for her, Esther “was in a flutter for a little while; and felt as if an old chord had been more coarsely touched than it ever had been since the days of the dear old doll, long buried in the garden” (154); when seeing Lady Dedlock for the first 
time, Esther describes how "very strangely, there was something quickened within me, associated with the lonely days at my godmother's; yes, away even to the days when I had stood on tiptoe to dress myself at my little glass, after dressing my doll. And this, although I had never seen this lady's face before in all my life — I was quite sure of it — absolutely certain” (290). Esther's doll becomes a travelling doll, who returns to the narrative at unexpected moments (and often with reference to dressing). ${ }^{4}$

Robyn L. Schiffman reads these reappearances of Esther’s doll through the Freudian uncanny, arguing that the doll's appearances occur at moments of distress and of the return of the repressed (163). Schiffman's analysis is persuasive but only tells half the story of this particular travelling doll, since the reappearance of the doll is not limited to Esther's narration, but extends to the wider textuality of Bleak House itself. Dolls travel through Hablot Browne’s illustrations for the novel, the first of these manifesting itself behind Esther's back while in Krook's shop in 'The Lord Chancellor Copies from Memory' (77), like some kind of companion spirit; more strikingly, because such incidents take place in the other narrative half of the novel, a doll also appears in “Tom All Alone’s” (709) and “The Appointed Time” (518). In the latter image the doll no longer seems an inanimate object but an affective observer of the scene, reacting to the scene of Krook's death with a look of horror. ${ }^{5}$ Two doll figures also feature in the lower left corner of Browne's wrapper for Bleak House, buffeted back and forth in a physical game. These appearances are not, of course, Esther's doll in the most literal sense. But neither can the visual reappearances of the doll be so easily dismissed in a text in which one doll has remarkable powers to return from the grave. ${ }^{6}$ Nor is Esther's doll alone. Dolls appear in Bleak House at the limits of identity; for instance, Grandfather Smallweed is thrown into a chair "like a broken puppet” (334) and then dragged upright "as easily as if he were a doll” (345). Rosa is described by Volumnia as having “a dolly sort of beauty” (449); more complexly, the narrator speculates on Hortense's response to Rosa's incursion into the Dedlock 
house: "She, Hortense, been in my Lady's service since five years, and always kept at the distance, and this doll, this puppet, caressed — absolutely caressed — by my Lady on the moment of her arriving at the house!" (188). ${ }^{7}$ A doll even appears at the boundaries of language: the 'patter artist' Swills satirically imitates the Coroner at the inquest into Hawdon's death, singing “tippy tol li doll, tippy tol lo doll, tippy tol li doll, Dee!” (179). Esther’s travelling doll and its mobile ghosts, therefore, haunt Bleak House, acting as a focus for questions of intersubjectivity, of how the individual defines herself in relation to others (Esther's doll looking at "no-one”), and the relationship between the private individual and the public sphere.

The doll figure who appears, disappears, and reappears, suggests a triangulation between Bleak House, the Travelling Doll Wonder, and the Freudian model of the fort-da game. In Beyond the Pleasure Principle (1920), Freud famously tells the story of a child (later identified as his grandson) whose favourite game is to play with a wooden reel attached by string, throwing it out of sight and registering this absence with the word 'fort' ('gone'). The child would then pull the reel back into sight, with a cry of 'da' ('there'). Freud comments that “As a rule one only witnessed its first act, which was repeatedly untiringly as a game in itself, though there is no doubt that the greater pleasure was attached to the second act” (15). Freud reads this play as the child's celebration of his cultural achievement of "the renunciation of instinctual satisfaction” (15), of allowing his mother to go away without protesting, and compensating for this loss "by himself staging the disappearance and return of the objects within his reach” (15). Michael Mangan has noted that this dramatisation of absence and recovery is played out in much conjuring, and while such a reading is centred on the subjectivity of the performer, Mangan argues that the conjuror invites the audience to replay the fort-da game in their own minds (Mangan 145-6). The fort-da game certainly shares the dramatic structure of the Travelling Doll Wonder, but in placing analytical emphasis on the importance of the act of the return, despite its relatively rarer performance (“As a rule, one only 
witnessesed its first act”), Freud is too quick to dismiss the pleasures of disappearance in and of itself. The Bonus Genius routine could end one of two ways; either by having the doll triumphantly return (as in Dickens' Travelling Doll Wonder), or by emphasising the impossibility of the disappearance itself. Alfred Stodare's version, which ends with the absence of the doll, gives a strangely psychoanalytic cast to the doll's final disappearance, albeit played with mock pathos: "Alas! He is gone in earnest, like the sojourner of a day.... When we have lost him, we feel our loneliness” (443). Jay Watson suggests a further point of comparison between fort-da and the Travelling Doll Wonder: rather than engineering the gradual disappearance of the mother, Watson argues that the game actually reinstates the mother as "a speaking, desiring subject” (Watson 465) by being interpreted as a doll game in which the reel represents not the mother, but the child himself, who then places himself in the maternal position, a configuration Freud refuses to see (489-90). Patricia Pulham agrees with Watson's analysis, suggesting (in Winnicottian terms) that “[t]he doll, as transitional object, 'performs' in a doll game that creates a transitional space in which identity and power can be explored: boys can become 'mothers' and girls can inhabit the 'phallic' power of the maternal body prior to being subjected to the patriarchal law of the father and the rigidity of a 'fixed' sexual identity” (Pulham 78-9). For Watson and Pulham the doll is always already travelling between undecidable significations of mother/child, and both of their analyses are suggestive for reading Dickens' magic routine, especially with regard to the magician's creation of a transitional space where identity and perception become vertiginously fluid.

Fort-da is also the narrative model of Bleak House, both structurally (in its there-gone doubled narrations), and diegetically. One way of reading Bleak House through conjuring is to suggest Esther's role as magician, one who makes her doll disappear and reappear at will as a compensation for her own lost mother. But, in the colonial context of the routine (both in terms of Dickens' patter and his Orientalist guise as Rhia Rhama Roos), Bleak House offers other 
doll surrogates. Allan Woodcourt, for instance, appears in the narrative as someone whose appearances are always already strictly controlled by Esther's narrative sleights of hand, most notoriously the way Esther suddenly reveals an unnamed Woodcourt at the end of chapter 13, after having omitted him from the narrative; a forgetting prompted by the preceding sentence’s emphasis on 'remembrance' (214). But the way in which he disappears and reappears in the narrative, travelling great geographical distances in the narrative blink of an eye, suggests the fort-da aspects of the Travelling Doll Wonder. The spectrally subjunctive quality of Woodcourt's name in his relation to Esther (“would court”) has been noted by critics such as Elizabeth A. Campbell (141), but the apparatus of Dickens' Travelling Doll Wonder suggests another reading: “wood caught.” Consider also Woodcourt’s Welsh ancestry, insisted on by his mother (who quotes extensively from 'Crumlinwallinwer' and 'the Mewlinwillinwodd' (470)), meaning that his first name, Allan, translates from the Welsh as the noun 'exit' or the adjective 'outside.' Woodcourt is, of course, Esther's exit from the labyrinth of the original Bleak House, but she also commands his exit from, and return to, the space of the novel. Although Woodcourt is one of the few characters to appear in both narrative halves of the text without punishment (other similarly transgressive characters must seemingly be punished), he nevertheless returns under Esther's narrative control, the implied addressee of the novel's final, incomplete question.

Suzanne Graver, among others, has identified such gaps and manipulations in Esther’s narration as a kind of double vision that replicates the doubleness of the novel's structure: an "uneasy and unequal relation that exists throughout her narration between her affirming or accommodating self and the critical or desiring self she at once suppresses and obliquely expresses” (3). While it would be easy to ascribe this more critical voice to Dickens himself, Graver notes moments where Esther herself draws attention to similar deceptions, in particular her reflections on the artifice of Jarndyce's use of the 'east wind' (Graver 9). If the magician 
practices misdirection, Graver (following Mary Poovey) characterises Esther’s doubled and deferred self as a practice of indirection. Esther's divided self finds a parallel in the conjuror; as Warren Steinkraus points out, “A conjuror must be double-minded as no other performer dares to be” (25), since there are really two performances going on; that perceived by the audience, and that performed by the magician. Yet there is also something inconsequential about this doubleness; the magician cannot resolve this division, since the performance depends on it, and likewise Esther "does not confront her self-divisions and conflicts; she just repeats them” (Graver 11). For Graver, Dickens performs a different kind of sleight of hand at the novel's conclusion: “While Esther's double-voiced discourse regularly reveals the selfannihilating pressure that an ethic of selflessness has exerted on her, the manipulated ending magically turns self-sacrifice into self-fulfillment, rendering self-denial an unequivocal good through a ruse” (Graver 12). Esther's selfhood at the end of the novel is still elsewhere, dependent on the image others hold up to her; Bleak House is, almost literally, a text of smoke and mirrors.

Esther's indirections, in suppressing her critical self, and her narrative misdirections in withholding - 'forgetting' - Woodcourt remind us that both secular magic and Bleak House depend on the tension between memory and amnesia. Bleak House is, on one level, a feat of memory: Esther Summerson relating her experiences from an anterior perspective in startling detail. But, as Robert Newsom points out, much of the effect of the novel depends on forgotten things, since (in the terms of Dickens' own reflection on the text) “[w]ithout such a 'forgetting' the familiar never can become strange or romantic to us” (86). Bleak House proceeds in what Newsom calls an "atmosphere of forgetting," in which the causes of Jarndyce and Jarndyce are lost to memory, and in which Esther is commanded to "Forget your mother” (Newsom 86-7). Elsewhere, John Jarndyce almost succeeds in planting a false memory in Esther when she comments that "[he] began to talk to me as confidentially, as if I had been in the habit of 
conversing with him every morning for I don’t know how long. I almost felt as if I had” (1178). Such forgettings and false recollections establish the prominence of the uncanny and of the divided self in the novel, not least because something must be repressed before it can return.

Secular magic, too, partakes of this strange tension between memory and amnesia. More recent theorisations of conjuring by practitioners themselves have made it clear that the experience of magic lies not in the moment of sleight of hand, but in the way this action is misunderstood and then repeatedly remembered, or more accurately, misremembered. The British magician Derren Brown, for instance, notes that "the magic I perform is the anecdote waiting to be told twenty years from now by my spectators” (13); that is, the precise moment of magic is always deferred and located in narrative memory. Derrida, too, hints at this inherent repetitiousness of the experience of magic in Specters of Marx, when he argues that "A conjuring trick in fact multiplies itself, it gets carried away with itself, and is unleashed in a series” (159). Here, the magician becomes decentred from the conjuring narrative; rather, it is the audience's embellished narration that consolidates magical experience. This suggests limitations to the tripartite structure of magic suggested by Jehangir Bhownagary, in which conjuring comprises three dramatic stages: mimicry, struggle, and vertigo (32). The mimicry stage is one of mimesis; in order to overturn the workings of the world, the conjuror must demonstrably exist in the real world of physical laws, not within some fantastical parallel universe. Once this actual world has been established, the conjuror can then set about destabilising it, and the basis of the struggle element is the intellectual competition between the performer and the spectator, who tries not to be fooled. Of course, the contest is uneven, and once the conjuror has overcome the challenge of the spectator's reason, a kind of mental confusion arises. This is the vertigo element: "at this point, the spectator complacently gives himself up with pleasure to having his normal perceptual interpretations violated, his lucidity led into a sort of voluptuous panic and his world of order and reason temporarily shattered" 
(Bhownagary 32). As a result the magician "shakes up the solidity and smugness of objects, conquering the reality of the material world by impregnating it with the nimbleness and effervescence of wit and skill... he leads the spectator into the turbulence of disordered reason” (32), an anticipation of Derrida's use of the language of vertigo in discussing conjuring in Specters of Marx (Derrida 159). ${ }^{8}$ In this somewhat problematically sexualised model (in which interpretations are 'violated,' the material world 'impregnated,' and the resultant panic 'voluptuous') the audience find pleasure in passivity, but are not credited with creative power themselves. I would therefore add a fourth term to Bhownagary's process: mimesis, struggle, vertigo, and misnarration. Conjuring, in effect, relies on selective and aestheticized forgetting that makes the remembered details all the more impressive (how many of Dickens' audience remember his hand going to his pocket? Or recall occasions when the doll's messages may have been less than apt?). But, by the same token, it is also possible to forget a conjuring performance entirely. Simon During's reading of Franz Kafka’s fragmentary tale of conjuring, “K,” emphasises the amnesiac qualities of conjuring, a lack of affective heft caused by a certain modality of magic being concerned not so much with troubling questions of belief, but rather with more technical questions of "How is it done?" (During 61). ${ }^{9}$ Since it "conceals its means and is relatively traceless” (During 61), secular magic makes itself a problematic subject for cultural history, consigned (as it often is) to the seemingly more trivial field of games and puzzles. Although During goes on to problematize such arguments (after all, he provides an extensive cultural history of secular magic, including its relations to fiction), an art form which depends on selective memory nevertheless runs the risk of being utterly forgotten.

Both Bleak House and conjuring produce their effects, therefore, by holding memory and amnesia in productive tension. Jordan offers a suggestive way out of this contradiction, reading Esther's “uncanny repetitions, vocal displacement, belated address, and fugitive temporality” in the context of trauma as explicated by Cathy Caruth (Jordan 47). Considering 
Esther not only as magician but as magician's audience, I suggest that there is something in the narrative of secular magic that resembles Caruth's model of trauma, when she proposes that "we can begin to recognize the possibility of a history that is no longer straightforwardly referential (that is, no longer based on simple models of experience and reference). Through the notion of trauma... we can understand that a rethinking of reference is aimed not at eliminating history but at resituating it in our understanding, that is, at precisely permitting history to arise where immediate understanding may not” (11; original emphasis). This kind of history, with its similarity to Bhownagary's vertigo, arises out of events which are not fully experienced or known at their moment of occurrence (as in Freud's example in Moses and Monotheism of the victim who, in truly Dickensian fashion, walks away, apparently unharmed, from a railway accident), and are only belatedly accessed through involuntary and unconscious repetition. Here we are back in the territory of the fort-da game and Beyond the Pleasure Principle, although Caruth claims a wider historical significance to Freud's model as bringing “into prominent view a larger conception of historical experience.... In the game of fort-da, that is, we already see what is implicit in the curious movement from the example of combat trauma to the death drive, the fact that the history of trauma, as a historical experience of a survival exceeding the grasp of the one who survives, engages a notion of history exceeding individual bounds” (66). I would suggest that, at its most effective, secular magic plays on similar structures of trauma, consisting of an instigating event which is not fully grasped at its moment, and which gains force from its repetition in the mind of the observer and its narration to others (just as Dickens' reputation as a conjuror is sealed not by his tricks in and of themselves, but by Jane Carlyle’s breathless account of them). To be sure, this is a replaying of memory as opposed to unconscious repetition of acts (and Freud makes the distinction clear), but there is something in both conjuring's frequent focus on the violation of bodies and the belatedness of magical effects that resonates with Freudian trauma theory and with Esther 
Summerson's own retrospectively narrated struggle for subjectivity and her perpetually returning doll. At its most effective, conjuring, like the traumatic accident, presents its viewers with "a crisis that is marked, not by a simple knowledge, but by the ways it simultaneously defies and demands our witness” (Caruth 5). ${ }^{10}$

Though magic often aestheticises bodily traumas, my claim is not so much that performance magic is itself a kind of trauma, but rather that they have a similar psychic structure. More specifically to Dickens, however, I suggest that Bleak House turns the wonder associated with images of conjuring into traumatic experience. The two key traumatic moments of Bleak House - the death of Jenny's baby and the discovery of Lady Dedlock's body - both draw on the iconography of the Travelling Doll Wonder, Both traumatic scenes of Esther's narration make the subtext of the Travelling Doll Wonder explicit. The first occurs when Esther and Ada are present at the death of Jenny’s baby, an episode immediately preceded by another reference to dolls (“If you was to leave me a doll, I shouldn’t nuss it” (132), says the brickmaker to Mrs Pardiggle). Esther's response to the indecency, the exposure, of this death is to cloak the child: "Presently I took the light burden from her lap; did what I could to make the baby’s rest the prettier and gentler; laid it on a shelf, and covered it with my own handkerchief” (134). With this shrouding, playing on the chapter title "Covering a Multitude of Sins" (114), the baby disappears from the narrative, although the handkerchief itself will reappear at another vertiginous moment of “whirling thoughts” (578); Esther’s recognition of Lady Dedlock as her mother when she appears with "my handkerchief, with which I had covered the dead baby" (578). Esther replays Rhia Rhama Rhoos' routine with the cloak covering the doll, the cloak performing a somewhat paradoxical role; introduced to the routine as a necessary accoutrement for travel, the cloak is necessarily what is left behind, as the excess which makes the trick work in the first place. ${ }^{11}$ The covering of the baby, of dressing the exposure of death, prefigures the scene near the end of the novel, when Lady Dedlock, exposed in both literal and metaphorical 
senses ("It is the figure of a woman, too; but it is miserably dressed" (864)), takes flight. Again, the key setting is Jenny’s house; Lady Dedlock exchanges clothes with her to evade suspicion. While on the chase, Esther slips into Bhownagary's vertiginous state whereby "the unreal things were more substantial than the real” (913); her response to the finding of Lady Dedlock’s body turns the vertiginous response to a simple substitution trick - Lady Dedlock's change of clothes - into trauma:

I could repeat this in my mind too, but I had not the least idea what it meant. I saw before me, lying on the step, the mother of the dead child. She lay there, with one arm creeping round a bar of the iron gate, and seeming to embrace it. She lay there, who had so lately spoken to my mother. She lay there, a distressed, unsheltered, senseless creature.... I saw, but did not comprehend, the solemn and compassionate look in Mr Woodcourt's face. I saw, but did not comprehend, his touching the other on the breast to keep him back (915)

Esther's experience eludes her at that moment; she does not know what she is seeing, creating a vertiginous state of mind which she is compelled to repeat (not least in the echoed "I saw, but did not comprehend”). But at this point, Lady Dedlock is at her most doll-like, in terms of the parallel Rainier Maria Rilke draws between the doll and the corpse. For Rilke, the silence and indifference of the doll to the child's emotions creates a sense of hollowness, "that heart-pause which could spell death” (Rilke 33). The discovery of Lady Dedlock’s corpse represents the transformed but still silent Dolly’s final return to the text of Bleak House.

If it seems that I have placed far too much critical weight on a single piece of entertainment in this reading of Bleak House, let me conclude by returning to the scene of Dickens' performance, and the testimony of one who witnessed the routine. Mamie Dickens, in My Father as I Recall Him (1897), recalls the wonder she felt at her father's magic shows, and in particular "the disappearance and reappearance of a tiny doll, which would announce 
most unexpected pieces of news and messages to the different children in the audience; this doll was a particular favorite, and its arrival eagerly awaited and welcomed” (34). The memory is a strange inversion of Esther Summerson's first account of Dolly, in which the doll is expecting her (28). As in Freud's explication of trauma, there is a tension between the familiarity of repetition and the irruption of the unexpected in Mamie's story: she knows the doll is coming, as a compulsively repeated performance, but when it does it brings "most unexpected” results (and, for Freud, the traumatic is that which occurs too soon (12)). Mamie's use of the doll as an image for her relationship with her father gives us a paratextual example of dolls as negotiations with the parent, to be placed alongside Esther's doll, Winnicott's transitional object, and Jay Watson's re-reading of Ernest Freud's cotton reel game. But Mamie’s story also demonstrates that the workings of the Travelling Doll Wonder depend on a traumatic double bind. If the audience remain unaware of how the trick is performed (and if it is done well), they are put into a vertiginous state of wonder, having not fully understood what they have seen, missing the perception of the crucial moment, and condemned to replay it in their minds. But, on the other hand, if they do detect the workings of the doll, the magical effect may well be lost, but a different narrative emerges based on the aestheticisation of a decapitated body. It is unclear if Mamie ever found out the secret of the doll, substituting one traumatic narrative for another, but secular magic continued to fascinate her. In November 1865, for instance, she wrote to Dickens asking for his views on Stodare's 'Sphinx' effect, another piece of conjuring based around decapitation, though here the head's disjuncture from the body becomes the visible deception rather than its means. Dickens, although disclaiming that "I have only seen it once; and it is so extraordinarily well done, that it ought to be observed closely several times” (Letters 11: 108), responded with an explanation which, while not wholly accurate, understood the basic workings of the routine through a confederate hidden in a box disguised to appear like a table. Dickens, too, acknowledges the physical trauma of 
magic, speculating that the curtain is immediately dropped once the effect is done to allow the assistant to escape from his hiding place, where he has been hiding in "an extremely constrained attitude” and "has no doubt had quite enough of it” (Letters 11: 108).

Mamie Dickens explicitly uses conjuring as a site for accessing childhood memories; Esther Summerson, I suggest, does so implicitly, her uncannily returning doll being a version of the complex narrative Dickens performed as Rhia Rhama Roos. But it is unsurprising that Mamie Dickens should associate conjuring with childhood. The temporality of secular magic is complex; in creating a kind of pleasurable trauma in its viewers, it seeks to project itself as the subject of future narration, the observer's anecdote or compulsively repeated memory (how was it done? Did I actually see what I saw?). But at the same time, the magic performance is always already a repetition of an earlier state. Norman Triplett argued that the experience of watching conjuring was to recover a repressed state of childhood:

We are all children at conjuring shows. We like it because we then get away temporarily from the shackling logic of our lives. The crust of nature is thin, and we easily slump through into a state, perhaps analogous to the old conditions when we took things for granted.... We cut loose from our higher centers and let the nerve impulses run through the easiest channels... and in this passivity there is pleasure. (506-7)

Triplett's analysis requires some revision: as Winnicott argues, the child with a transitional object is not quite at a stage of reality-testing (12), and as a result cannot be susceptible to conjuring, since conjuring relies on the subversion of established realities and of mimetic representations. The child Esther is not the magician of Bleak House; rather, it is the adult narratorial Esther who performs this role in making her doll and finally herself disappear and reappear (indeed, the two become linguistically conflated when Esther promises that "my little body will soon fall into the back-ground now" (40)). ${ }^{12}$ So while we are not children at conjuring 
shows, we are certainly child-like. Triplett's analysis looks forward to Bhownagary's model of conjuring, in which there is pleasure in passivity, but it echoes Dickens' textual concerns with perception, the limits of narrative omniscience, and the figure of the child. The crust of nature is indeed thin in Bleak House, lingering on the romantic side of familiar things, and a reading of the novel in the context of secular magic invites us to consider how both discourses conceive of (as Coppa, Hass, and Peck put it) “alternatives to seemingly settled realities” (10). While my focus here has been Bleak House, the travelling doll traverses Dickens' wider work. ${ }^{13}$ When, at the opening of the thirty-third chapter of The Old Curiosity Shop, the narrator changes the focus from Mrs Jarley to Sampson Brass, the switch is not accomplished by simple juxtaposition, but a movement of rapid, magical travel: "the historian takes the friendly reader by the hand, and springing with him into the air, and cleaving the same at a greater rate than ever Don Cleophas Leandro Perez Zambullo and his familiar travelled through that pleasant region in company, alights with him upon the pavement of Bevis Marks” (250). A similar movement occurs at the start of chapter nine of Barnaby Rudge (1841): "Chroniclers are privileged to enter where they list, to come and go through keyholes, to ride upon the wind, to overcome, in their soarings up and down, all obstacles of distance, time, and place” (119). The process of such rapid changes is eventually brought closer to performance technology in the extended metaphor of the magic lantern in Pictures from Italy (1846), not least the dissolving views of Dickens' sudden transitions between Modena, Padua, Bologna, Ferrara, and eventually Venice (77-8). Such rapid exchanges, like the final unfinished sentence of Bleak House, prompt the audience's response to the adept conjuror: after all these scenes of wonder, the audience are left asking “what will happen next?”

University of Portsmouth, UK. 


\section{$\underline{\text { Notes }}$}

${ }^{1}$ There is not space available to consider the implications of Forster as Dickens' magical assistant, but such an arrangement raises questions of the parallel between the work of the conjuror's assistant and Forster's own role in creating an image of Dickens. As Francesca Coppa notes, reading secular magic in the context of Marxist conceptions of class, "The strengthening of magic's association with the figure of the Western capitalist happened simultaneously with the widespread addition of assistants to the magic act. After all, what's a capitalist without a labor force? And in stage magic, as in industry, it's often the assistant who actually does the work of the trick" (Coppa 86).

${ }^{2}$ During briefly outlines Dickens’ involvement with conjuring (113-4); more detailed, if now dated, accounts can be found in Staff and Tigner. The only recent critically sustained treatment of Dickens and conjuring is Helen Groth's account of the theatrical adaptation of The Haunted Man and its use of the optical illusion Pepper's Ghost.

${ }^{3}$ Colonialism comes into play in this narrative, especially with the mention of Algiers; as narrated in chapter twenty of his Memoires, Eugene Robert-Houdin had been sent by the French government to Algeria to demonstrate feats of conjuring as a means of undermining the Marabout uprising by demonstrating the superiority of Western secular conjuring to supposedly superstitious beliefs.

${ }^{4}$ Here, Dolly prefigures another travelling doll wonder: Jenny Wren's doll in Our Mutual Friend. As Adrian Poole notes, Marcus Stone's illustration of what appears to be Jenny's puppetry had become misplaced in the two volume 1865 edition of Our Mutual Friend and moved to a different chapter altogether (Dickens Mutual xxxiv). Jenny Wren is also a kind of conjuror, in her role in the convalescence of Eugene Wrayburn; as Hilary Schor notes, "the proper end of [Our Mutual Friend] is to bring a dead man to life by teaching him to say one 
magic word, and that word is 'wife'” (178), though Schor goes on to suggest that it is "only by the deepest distrust of the magic of fictions can Dickens write his last novel” (178).

${ }^{5}$ Emily Madsen reads the blackness of these dolls as an engagement with empire and commerce; an intriguing reading, but one which tends to foreclose psychoanalytic readings of these appearances; likewise, the reading of their darkness as racial signifier overlooks the pervasive context of dirt and the abject in the illustrations.

${ }^{6}$ Moving beyond the merely textual references to the doll's reappearance, John O. Jordan reads the image of Esther and Lady Dedlock's reunion, 'Lady Dedlock in the Wood,' as one haunted by another temporality; the image of Charley in the background, gathering flowers under the tree, becomes the image of Esther burying Dolly (Jordan 38-41), who makes yet another miraculous reappearance.

${ }^{7}$ There is much to note here; the transference onto Rosa of the status of puppet is neatly mirrored in the narrator ventriloquising Hortense's response in indirect discourse. One might also note the conflation of doll with puppet, the distinction being that a puppet implies an operator behind it, a motive force that can be attributed and thus explained; a doll can be uncanny in a way that a puppet cannot (in this respect, Dickens' magic routine is a puppet, rather than a doll, show). The question of Hortense's own subjectivity and its relationship to dollhood (or more accurately, the status of the automaton) is raised in her climactic confrontation with Bucket, when she stands with "her arms composedly crossed, but with something in her dark cheek beating like a clock” (830).

${ }^{8}$ Michael Hass describes the effects of performance magic in a similar way, arguing from a Kantian perspective that conjuring can be "transporting, pleasurable, and sublime” (Hass 14). ${ }^{9}$ During sees the unmemorable performance of Kafka's conjuror as replicated in the story's form and its narrative evasion, "which slides from sleight of hand to narrative slightness” (61). In Kafka’s fragment, During notes, the focus of interest is the crowd drawn by the performance, 
rather than the performance itself. The implications of this are twofold: firstly, a problematisation of the relationship between modernist literature and magic, since the former valorizes an interiorised individuation that the surface trickiness of stage magic cannot approximate; and secondly, a devaluation of magic as artistry.

10 The best example in Victorian culture of the effect of conjuring as exceeding simple knowledge occurs in a text closely related to Dickens, Elizabeth Gaskell's Cranford (1851), when the magic of Signor Brunoni still amazes despite Miss Pole’s overly schematic explanations of conjuring technique.

${ }^{11}$ Stodare's version explains the cloak through the context of empire: "It is clear that he has chosen to go to a hot climate, as he has left his cloak behind him” (442). Many commercial versions of the Bonus Genius have the doll already fully dressed (although the version in Hocus Pocus Iunior involved a naked male doll), but the point remains that the doll has travelled outside without its travelling cloak.

${ }^{12}$ This argument extends to the structure of the novel itself; Newsom suggests that Esther and the third person narrator are alter egos on the basis that Esther's voice often slips into that of the third person narrator (87); conversely, Audrey Jaffe notes that the third person narrator briefly lapses into the first person (Jaffe 130).

${ }^{13}$ The doll makes another uncanny appearance in a related text, Mark Lemon’s The Enchanted Doll (1849), a tale of a dollmaker whose envy and anger become externalised in a magical black doll given to him by the fairy Malice. Like Dickens' travelling doll, the dynamic of Lemon's tale relies on the surprise reappearances of a doll considered to have disappeared; the comparison of the magic doll to the early modern shop sign for chandlers connects the tale to the manner in which a black doll recurs throughout Browne’s illustrations for Bleak House (in this context, 'Tom All Alone's' in particular). Lemon's travelling doll returns home to the 
Dickens family by way of the tale's dedication to Kate and Mamie Dickens. I am grateful to the anonymous reviewer of this article for bringing Lemon's text to my attention.

\section{Works Cited}

Anderson, John Henry. The Fashionable Science of Parlour Magic. London: Great Wizard of the North, 1855.

Arnold, George, and Frank Cahill. The Magician's Own Book, or the Whole Art of Conjuring. New York: Dick \& Fitzgerald, 1862.

Beckman, Karen. Vanishing Women: Magic, Film, and Feminism. Durham, NC: Duke UP, 2003.

Bhownagary, Jehangir. “Creativity of the Magician.” Leonardo 5.1 (1972): 31-35.

Binet, Alfred. “La Psychologie de la Prestigidation.” Revue des Deux Mondes, 15 Oct 1894: 903-22.

Brown, Derren. Pure Effect: Direct Mindreading and Magical Artistry. Humble, TX: H\&R Books, 2002.

Butterworth, Peter. Performing Magic on the Early English Stage. Cambridge: Cambridge UP, 2005.

Carlyle, Thomas, and Jane Welsh Carlyle. The Collected Letters of Thomas and Jane Welsh Carlyle. Vol. 17. Eds. Charles Richard Sanders, Kenneth J Fielding and Clyde de L. Ryals. Durham: Duke UP, 1990.

Campbell, Elizabeth A. Fortune's Wheel: Dickens and the Iconography of Women's Time. Athens: Ohio UP, 2003.

Caruth, Cathy. Unclaimed Experience: Trauma, Narrative, and History. Baltimore: Johns Hopkins UP, 1996.

Coppa, Francesca. “The Body Immaterial: Magicians’ Assistants and the Performance 
of Labour.” Coppa, Hass and Peck 85-106.

Coppa, Francesca, Lawrence Hass, and James Peck, eds. Performing Magic on the Western Stage: From the Eighteenth Century to the Present. Basingstoke: Palgrave Macmillan, 2009.

Derrida, Jacques. Specters of Marx: The State of the Debt, the Work of Mourning, and the New International. Trans. Peggy Kamuf, 1993. London: Routledge, 2006.

Dever, Carolyn. Death and the Mother from Dickens to Freud: Victorian Fiction and the Anxiety of Origins. Cambridge: Cambridge UP, 1998.

Dickens, Charles. Barnaby Rudge. 1841. London: Penguin, 1997.

- - -. $\quad$ Bleak House. 1852-3. London: Penguin, 1996.

- - - . Dombey and Son. 1846. London: Penguin, 1985.

- - - . The Letters of Charles Dickens. Eds Angus Easson, Graham Storey and Kathleen Tillotson. 12 vols. Oxford: Clarendon Press, 1965-2002.

- - - . Martin Chuzzlewit. 1843-4. London: Penguin, 1986

- - - . The Old Curiosity Shop. 1841. London: Penguin, 1985.

- - - . Our Mutual Friend. 1865. London: Penguin, 1997.

- - -. $\quad$ Pictures from Italy. 1846. London: Penguin, 1998.

Dickens, Mamie. My Father as I Recall Him. 1896. Cambridge: Cambridge UP, 2014.

Dixon, Edmund Saul. “Out-Conjuring Conjurors.” Household Words 9 April 1859: 433-56.

During, Simon. Modern Enchantments: The Cultural Power of Secular Magic.

Cambridge, MA: Harvard UP, 2002.

Fischer, Lucy. “The Lady Vanishes: Women, Magic, and the Movies.” Film Before Griffith. Ed. John L Fell. Berkeley: U of California P, 1983. 339-54.

Forster, John. The Life of Charles Dickens. Vol. 3. London: Chapman and Hall, 1874. Freud, Sigmund. Beyond the Pleasure Principle. 1920. The Standard Edition of the Complete 
Psychological Works of Sigmund Freud Vol. 18. Trans. James Strachey. London: Hogarth Press, 1975. 3-144.

Gaskell, Elizabeth. Cranford. 1851. Oxford: Oxford UP, 2011.

Glavin, John. After Dickens: Reading, Adaptation and Performance. Cambridge:

Cambridge UP, 1999.

Graver, Suzanne. "Writing in a 'Womanly' Way and the Double Vision of Bleak House.” Dickens Quarterly 4.1 (1987): 3-15.

Groth, Helen. “Reading Victorian Illusions: Dickens’s Haunted Man and Dr Pepper’s Ghost.” Victorian Studies 50.1 (2007): 43-65.

Hass, Lawrence. “Life Magic and Staged Magic: A Hidden Intertwining.” Coppa, Hass and Peck 13-32.

Herbert, Christopher. “The Occult in Bleak House.” Novel 17.2 (1984): 101-15.

Hoffmann, Professor [Angelo John Lewis]. Modern Magic: A Practical Treatise on the Art of Conjuring. 1873. New York: Biblo and Tannen, 1987.

Illustrated Catalogue of Conjuring Tricks, Magical and Electrical Apparatus, Ingenious Puzzles, \&c. London: W. \& F. Hamley, n.d. [c.1890]. Jaffe, Audrey. Vanishing Points: Dickens, Narrative, and the Subject of Omniscience. Berkeley: U of California P, 1991.

Jastrow, Joseph. "Psychological Notes upon Sleight of Hand Experts.” Scientific American Supplement, 19 Dec 1896: 488-9.

- - - . “The Psychology of Deception.” Popular Science Monthly Dec 1888: 145-7. John, Juliet. Dickens’ Villains: Melodrama, Character, Popular Culture. Oxford: Oxford UP, 2003.

Jordan, John O. Supposing Bleak House. Charlottesville: U of Virginia P, 2011. Lemon, Mark. The Enchanted Doll: A Fairy Tale for Little People. London: Bradbury and 
Evans, 1849.

Madsen, Emily. "Phiz’s Black Doll: Integrating Text and Etching in Bleak House.” Victorian Literature and Culture 41.3 (2013): 411-33.

Mangan, Michael. Performing Dark Arts: A Cultural History of Conjuring. Bristol: Intellect, 2007.

Marx, Karl. Capital: A Critique of Political Economy Vol. 1. Trans. Ben Fowkes. 1867. London: Penguin, 1976.

Mayhew, Henry. London Labour and the London Poor. Vol. 3. 1851. London: Frank Cass, 1967.

Newsom, Robert. Dickens on the Romantic Side of Familiar Things: Bleak House and the Novel Tradition. New York: Columbia UP, 1977.

Pulham, Patricia. Art and the Transitional Object in Vernon Lee’s Supernatural Tales. Farnham: Ashgate, 2008.

Rilke, Rainier Maria. “Dolls: On the Wax Dolls of Lotte Pritzel.” Essays on Dolls: Kleist, Baudelaire, Rilke. Trans. and Eds. Idris Parry and Paul Kegan. London: Penguin, 1994. 26-39.

Robert-Houdin, Eugene. Memoirs of Robert-Houdin: Ambassador, Author and Conjuror. Trans. F. C. L. Wraxall. Philadelphia: George Evans, 1859.

Schiffman, Robyn L. "Wax-Work, Clock-Work and Puppet Shews: Bleak House and the Uncanny.” Dickens Studies Annual 30 (2001): 159-71.

Schlicke, Paul. Dickens and Popular Entertainment. London: Allen and Unwin, 1985.

Schor, Hilary M. Dickens and the Daughter of the House. Cambridge: Cambridge UP, 1999.

Steinkraus, Warren. “The Art of Conjuring.” Journal of Aesthetic Education 13.4 (1979): 17-27.

Staff, Frank. "Dickens the Conjuror, and a Mystery Solved.” The Dickensian 39 
(1942): 61-3.

Stodare, Colonel Alfred [Joseph Stoddart]. Stodare’s Fly Notes: or, Conjuring Made Easy. London: G. Routledge \& Sons, 1867.

Sully, James. Illusions: A Psychological Study. London: Kegan Paul, 1887.

Tigner, Steven S. “Charles Dickens In and About Magic: A Preliminary Sketch.” Journal of Magic History 1.2 (1979): 88-110.

Triplett, Norman. “The Psychology of Conjuring Deceptions.” American Journal of Psychology 11.4 (1900): 439-510.

Vlock, Deborah. Dickens, Novel Reading and the Victorian Popular Theatre. Cambridge: Cambridge UP, 2006.

Watson, Jay. "Guys and Dolls: Exploratory Repetition and Maternal Subjectivity in the Fort-da Game.” American Imago 52.4 (1995): 463-503.

Winnicott, D. W. Playing and Reality. 1971. Abindgon: Routledge, 2012. 